\title{
Eradication of Paropsisterna beata (Newman) (Coleoptera: Chrysomelidae) in a semi-rural suburb in New Zealand
}

\author{
Emmanuel Yamoah ${ }^{1 *}$, Dave Voice ${ }^{2}$, Disna Gunawardana ${ }^{3}$, Brad Chandler ${ }^{1}$ and Don Hammond ${ }^{4}$
}

\begin{abstract}
Background: A large population of Paropsisterna beata (eucalyptus leaf beetle) was detected on Eucalyptus nitens (H. Deane \& Maiden) Maiden (Myrtaceae) at Whitemans Valley, a suburb east of Upper Hutt, Wellington, in 2012. The suburb is a semi-rural residential area with a large number of eucalypt, planted for amenity, shelterbelt and firewood. Surveillance to delimit spread showed that the beetle population was confined to about 0.7 ha consisting of about 40 eucalypts. The Ministry for Primary Industries (MPI) initiated a response to eradicate the beetle population.

Findings: Aerial applications of Dominex EC 100 (alpha-cypermethrin) and ground applications of Talstar (bifenthrin) respectively over a 15-month period targeted the adults and larvae in the foliage and the pre-pupae, larvae and emerging adults in the leaf litter. Removal of overwintering habitat by stripping loose bark from host trees further reduced the beetle population. Following these treatments, the beetle has not been detected through a series of surveys using light traps, bark inspection, sticky tapes, visual inspection from the ground, climbing and felling host trees for inspection for 2 years since the last detection of two adults on neighbouring trees.

Conclusions: The $P$. beata population has been successfully eradicated using a combination of aerial and groundbased application of insecticides. The use of precision aerial applications (spot-spraying) has provided an additional tool for incursion response.
\end{abstract}

Keywords: Eucalyptus, Paropsisterna beata, Eradication, Surveillance, Aerial spot-spraying

\section{Findings \\ Introduction}

Paropsisterna beata (eucalyptus leaf beetle) is a native Australian species that feeds on a range of Eucalyptus species including commercial and amenity species grown in New Zealand. Eucalyptus species are the only known host of P. beata with Eucalyptus nitens (H. Deane \& Maiden) Maiden, Eucalyptus camaldulensis Dehnh. and Eucalyptus pilularis Sm. being of commercial value in New Zealand. Eucalyptus species are grown throughout the North and South Islands of New Zealand with a total area for commercial plantation estimated at 28,600 ha.

In the field, most damage is caused by the larval stages with the third and fourth larval instars responsible for

\footnotetext{
* Correspondence: emmanuel.yamoah@mpi.govt.nz

${ }^{1}$ Ministry for Primary Industries, PO Box 2526, Wellington, New Zealand Full list of author information is available at the end of the article
}

approximately $90 \%$ of larval feeding damage (Johns et al. 2004). Adults and larvae feed on young foliage, with adults feeding preferentially on older foliage and ovipositing on juvenile foliage (Johns et al. 2004). Defoliation reduces plant growth and consequently timber production. Under heavy infestations, prolonged defoliation over several growing seasons can lead to a "broom-topped" appearance or tree dieback or even death in severe cases. Intense adult feeding early in the season promotes a second flush of foliage growth which is the preferred food for the larvae. The most vigorous feeding by adults occurs just before overwintering. Adult beetles overwinter (reproductive diapause) under the loose bark of host trees, occasionally in crevices of seasoned wood or in the leaf litter under the tree canopy.

Paropsine beetle species, which are regarded as minor pests in their native countries, have become serious

\section{Springer}


pests in New Zealand due to the absence of significant natural enemies (Edwards and Suckling 1980).

A simplified GIS program DIV-GIS (V. 7.5.) (www.divagis.org) was used with BIOCLIM algorithm to model the potential distribution of this pest in New Zealand. The results showed that $P$. beata has the potential to establish in most parts of the North Island due to similar climatic conditions to areas of its distribution in Australia (its native area and the only place worldwide where it is known to exist). A few paropsine species have established outside their native range and include Paropsis charybdis (which is widespread in New Zealand) (Gordon 2010), Trachymela sloanei which is also established in New Zealand (Gordon 2010) as well as in southern California (Millar et al. 2003) and Paropsisterna selmani (in Ireland) (Malumphy and Anderson 2015). In 2013, it was estimated through a cost benefit analysis carried out by the Ministry for Primary Industries (MPI) that if $P$. beata were to establish in New Zealand, potential losses to the forest industry over 20 years could be worth $\$ 23$ million in lost wood pulp production (unpublished). ${ }^{1}$

The first known incursion of P. beata in New Zealand occurred in August 2012. The Ministry for Primary Industries initiated a response with the aim of eradicating the beetle population. This paper reports on the response operations.

\section{Methods \\ The incursion}

The eucalyptus leaf beetle was detected at Whitemans Valley, Upper Hutt (at the southern end of the North Island) in August 2012 when a property owner felled some E. nitens for firewood. Samples were sent to the Plant Health and Environmental Laboratory (PHEL) where they were identified as $P$. beata. This identity was confirmed by Dr. Chris Reid from the Australian Museum, Sydney. A technical advisory group (TAG) was formed to provide technical advice on the response operations.

\section{Survey schedule}

Delimiting survey A delimiting survey on the distribution of the beetle was carried out at Whitemans Valley in February 2013, which consisted of surveying a $>2-3$ $\mathrm{km}$ radius (zone $\mathrm{C}$ ) and a $0-0.5-\mathrm{km}$ radius (zone $\mathrm{A}$ ). $\mathrm{A}$ combination of sampling methods (i.e. felling, climbing and ground visual inspection) was used in the delimiting survey.

Felling involved cutting each tree at ground level and inspecting the foliage. Climbing involved either scaling of the tree trunk or the use of elevated platform vehicle (EPV) to inspect defoliated branches and foliage of host trees. Branches with fresh growth and pest-damaged leaves were removed for close inspection. Visual inspection of intact foliage from the ground was used for trees less than $10 \mathrm{~m}$ in height and was either by naked eye or with binoculars.

Additional surveys A further seven surveys within zone A were carried out using a combination of bark inspection, ground observation, climbing and tree felling over the following two years (Table 1). Other survey methods used in zone A included the use of two light traps and applying sticky tapes on trunks of $50 \%$ of the host trees (three to four bands of tapes per trunk) at appropriate times during the eradication phase of the programme. Fact sheets were distributed to New Zealand forest growers and Whitemans Valley residents to enhance passive surveillance. A survey of zone B was carried out in winter (July 2014) using mainly bark and litter inspections. The bark inspection involved climbing of selected eucalypt trees and stripping down about one third of the loose bark from the bottom, middle and top sections of the trunk. Inspections of the bark included searching for insects living under the bark and those that were inside the tightly rolled up pieces of bark (this was found to be a favoured refuge). Ground inspection was carried out around selected trees that had shed bark and leaves.

A sample detection plan was developed based on the method reported by Kean et al. (2015). For surveillance purposes, trees were grouped into functional units (i.e. eucalypt stands) although the survey unit was one eucalypt tree. Eucalypt stands within each of the three zones were mapped, and the approximate number of trees and average height per stand were estimated. The number of trees required to be sampled to give $95 \%$ confidence at 1 and $5 \%$ prevalence was determined using the sample formula by Kean et al. (2015). The required number of trees was allocated across the stands in relation to the number of trees present in each stand. Felling was assigned the highest sample sensitivity or effectiveness (Table 2) because the probability of detecting the beetle when a tree was felled and inspected was deemed to be higher than either inspection from the ground or by climbing.

For the delimiting survey, 165 trees out of 714 were sampled in zone C and 120 trees out of 192 were sampled in zone A (Table 2). All adult beetles sampled during this survey were identified by morphology, and immature stages (including egg masses, larvae and pupae) were identified by DNA analysis. DNA was isolated from individual specimens using prepGEM insect DNA extraction kit (ZyGEM Corporation Ltd, New Zealand) according to the manufacturer's instructions. The DNA was amplified using the primer pair, LCO1490 and HCO2198 (Folmer et al. 1994). PCR products were directly sequenced by Ecogene, New Zealand. Identification of immature stages was done by sequence comparison of the adult $P$. beata specimen as no sequences were available 
Table 1 Survey dates, operational activities undertaken for eradication of Paropsisterna beata at Whitemans Valley and number of individuals collected

\begin{tabular}{|c|c|c|c|}
\hline Survey type and zone $e^{a}$ & Operational activities & Start date & No. of $P$. beata collected (all life stages) \\
\hline \multirow[t]{2}{*}{ Delimiting survey (zones A and C) } & \multirow{2}{*}{$\begin{array}{l}\text { Bark inspection, ground observation, } \\
\text { climbing and tree felling }\end{array}$} & \multirow[t]{2}{*}{22 Feb 2013} & Zone C: 0 \\
\hline & & & Zone A: 13 \\
\hline \multirow[t]{6}{*}{ Pre-spray survey (zone A) } & Bark inspection, ground observation, climbing & 18 Apr 2013 & 0 \\
\hline & Aerial and ground spraying & 26 Apr 2013 & \\
\hline & Aerial and ground spraying & 08 May 2013 & \\
\hline & Tree felling, removal of loose bark & 13 Aug 2013 & 50 \\
\hline & Ground spraying & 13 Sep 2013 & \\
\hline & Application of sticky bands to trees & 13 Sep 2013 & \\
\hline \multirow[t]{5}{*}{ Survey (zone A) } & $\begin{array}{l}\text { Bark inspection, ground observation, } \\
\text { climbing and tree felling }\end{array}$ & 04 Oct 2013 & 2 \\
\hline & Ground spraying & 07 Oct 2013 & \\
\hline & Aerial spraying & 19 Oct 2013 & \\
\hline & Aerial spraying & 02 Nov 2013 & \\
\hline & Sticky-tape surveillance & 25 Nov 2013 & \\
\hline \multirow[t]{5}{*}{ Survey (zone A) } & $\begin{array}{l}\text { Bark inspection, ground observation, } \\
\text { climbing and tree felling }\end{array}$ & Nov-Dec 2013 & 0 \\
\hline & Light-trapping surveillance & Dec-Jan 2014 & \\
\hline & Ground spraying & 18 Dec 2013 & \\
\hline & Aerial and ground spraying & 24 Feb 2014 & \\
\hline & Aerial spraying & 03 Mar 2014 & \\
\hline Survey (zone A) & Bark inspection, ground observation, climbing & 17 Mar 2014 & 0 \\
\hline \multirow[t]{2}{*}{ Survey (zones A and B) } & Climbing, bark and litter inspections & $21 \mathrm{Jul} 2014$ & 0 \\
\hline & Ground spraying & $21 \mathrm{Jul} 2014$ & \\
\hline Survey (zone A) & Bark inspection, ground observation, climbing & 18 Feb 2015 & 0 \\
\hline Survey (zone A) & Bark inspection, ground observation, climbing & 6 Oct 2015 & 0 \\
\hline
\end{tabular}

Zone $\mathrm{A}$ : $0-0.5-\mathrm{km}$ radius; zone $\mathrm{B}$ : $>0.5-2-\mathrm{km}$ radius; zone $\mathrm{C}:>2-3-\mathrm{km}$ radius

in BOLD and NCBI online databases for species identification.

\section{Aerial insecticide applications}

Broadcast spraying The TAG advised the response team on the choice of insecticides for spraying. The synthetic pyrethroid alpha-cypermethrin was chosen for the aerial applications because it has been used successfully to control $P$. charybdis, a closely related species that causes damage in commercial eucalypt plantations in the Southland region of the South Island and the central North Island (Bain et al. 2009). Accurate application of the spray was essential in the response planning since the target trees were in a valley surrounded by residential houses where drinking water was collected from rooftops. Strand et al. (unpublished) ${ }^{2}$ used the aerial spray drift model AGDISP (Continuum Dynamics, Inc., New Jersey, USA) (Thistle 2003) to evaluate trade-offs

Table 2 Sample methods to detect Paropsisterna beata with $95 \%$ confidence at a design prevalence of 1 or 5 \% within zones A, B and C

\begin{tabular}{lllll}
\hline Sample method & Sample sensitivity (\%) & $\begin{array}{l}\text { Zone A sample size }{ }^{\mathrm{a}} \\
\left(P^{\mathrm{b}}=0.05\right)\end{array}$ & $\begin{array}{l}\text { Zone B sample size } \\
(P=0.01)\end{array}$ & $\begin{array}{l}\text { Zone C sample size } \\
(P=0.05)\end{array}$ \\
\hline Felling & 90 & 1 & - & 2 \\
Bark and litter inspection & 80 & - & 359 & - \\
Climbing or EPV & 50 & 109 & - & 114 \\
Visual inspection from ground & 10 & 10 & 359 & 49 \\
Total trees sampled & - & 120 & 2730 & 165 \\
Number of eucalypt trees within the zone & - & 192 & 714 \\
\hline
\end{tabular}

${ }^{a}$ Number of trees

${ }^{\mathrm{b}} P$ is design prevalence 
between drift and efficacy. From this analysis, they determined a $255-\mu \mathrm{m}$ volume median diameter droplet released at $8 \mathrm{~m}$ and with wind speeds below $4 \mathrm{~km} \mathrm{~h}^{-1}$ would provide the best compromise between maximising coverage and reducing risk of off-target drift. These conditions were used for all aerial sprayings.

A helicopter was used to blow dew off the trees prior to spraying. The insecticide Dominex EC 100 (Etec Crop Solutions, Auckland, New Zealand; active ingredient $10 \%$ alpha-cypermethrin ${ }^{3}$ ) was applied aerially to infested trees at a rate of $5 \mathrm{~mL} \mathrm{~L}^{-1}$ of water and $2 \mathrm{~mL} \mathrm{~L}^{-1}$ of Driftstop (Nufarm Limited, Auckland, New Zealand) adjuvant. Each application was made between 7 and 8 am using a conventional spray boom on a helicopter to deliver $200 \mathrm{~L}$. The aerial applications occurred in April and October of 2013 and February 2014. Each application was repeated 1-2 weeks later giving a total of six aerial applications (Table 1).

Spot-spraying This technique used a slight modification of the spot-gun method developed by Strand et al. (2014) and was used for spraying trees close to houses where broadcast aerial spraying would have been unacceptable to the residents. The spot-spraying technique involved the blocking off of all the nozzles on the conventional boom and only using two separate nozzles mounted on one side of the boom. About $2 \mathrm{~L}$ of insecticide (the same type and rate as used above) were applied per tree. The spotsprayings occurred in October 2013 and February 2014 on the same day as the boom spraying. Each application was repeated 1-2 weeks later for a total of four applications.

\section{Ground applications of insecticide}

Seven ground sprays were applied between April 2013 and July 2014, mostly during the cool months (autumn and winter). Three of them were undertaken on the same day as the aerial application, once the first dose of insecticide had dried, to target the adults and larvae that might have dropped to the ground during the aerial spraying. Talstar (FMC Corporation, Philadelphia, PA, USA; active ingredient $8 \%$ bifenthrin $^{4}$ ) was sprayed at $2 \mathrm{~mL} \mathrm{~L}^{-1}$ on the ground area of the tree canopy and along the trunk up to 3-4 $\mathrm{m}$. Tree trunks were sprayed to the point where liquid ran off to ensure penetration under loose bark, which is known to be a preferred habitat for resting adult beetles.

\section{Findings and discussion}

An indication of the spread of the incursion was initially determined by a delimiting survey in zones A and C, Table 1. This survey was mainly based on visual inspection because there were no effective lures available for trapping Paropsisterna species. Only a few trees were sampled by felling due to the destructive nature of this sampling method and the potential for forced dispersal even though this method had the highest sample sensitivity or effectiveness (Table 2). Detection of the beetle within a $>2-3-\mathrm{km}$ radius from the incursion site would imply a widespread incursion, and therefore, eradication would not have been feasible due to the presence of numerous host trees and houses. None of the samples collected from zone $\mathrm{C}$ were identified as $P$. beata but were identified as either $P$. charybdis or species belonging to Acanthosomatidae. P. charybdis egg masses parasitised by Enoggera nassaui (Hymenoptera: Pteromalidae) (a parasitoid introduced to control $P$. charybdis) were also detected. Other important pests of eucalypts observed included Phylacteophaga froggatti (Hymenoptera: Pergidae), Gonipterus platensis (Coleoptera: Curculionidae) and Opodiphthera eucalypti (Lepidoptera: Saturniidae), all of which are established in New Zealand. In contrast to the results from zone $\mathrm{C}$, a high population (hundreds) of $P$. beata was observed in zone A. These were confined to about 0.7 -ha area containing $40 \mathrm{E}$. nitens trees in the same area where the incursion was initially detected. Thirteen samples were collected (four adults and nine larvae (first, second and fourth instars)), and all were identified as $P$. beata (Fig. 1). The presence of several adults and larvae is evidence that a breeding population of $P$. beata had established in the North Island.

In October 2013, almost a year after the first detection, another survey of zone A showed that the size of the known infested area had increased with two adult beetles found on eucalypts about $18 \mathrm{~m}$ away from the known infested site.

During diapause, adult beetles aggregate under tightly rolled up eucalypt bark or in the leaf litter under the tree canopy; therefore, the chances of detecting them at these locations in winter is high. As evidence of this, about 50 adult $P$. beata were found under eucalypt bark during tree felling operation within zone A in winter of 2013 (Table 1). The light traps and sticky tapes caught mostly flies, moths and butterflies and therefore were ineffective for trapping beetles.

The eucalypts at the incursion site had an average height of 20-30 m, so the only effective insecticide application method was by aerial spraying. Given the nature of the environment, it was important to minimise spray drift. Prior modelling using specialised software (spray drift AGDISP) enabled subsequent aerial applications to be undertaken with minimum drift, thus maximising efficacy for a successful eradication within a semi-rural environment. Moreover, the spot-spraying technique allowed better targeted treatment than broadcast spraying, which provided a safer option for isolated trees close to houses. Spot-spraying was also applied to trees that had been sprayed using a conventional boom because it provided good coverage of insecticide throughout the canopy and 


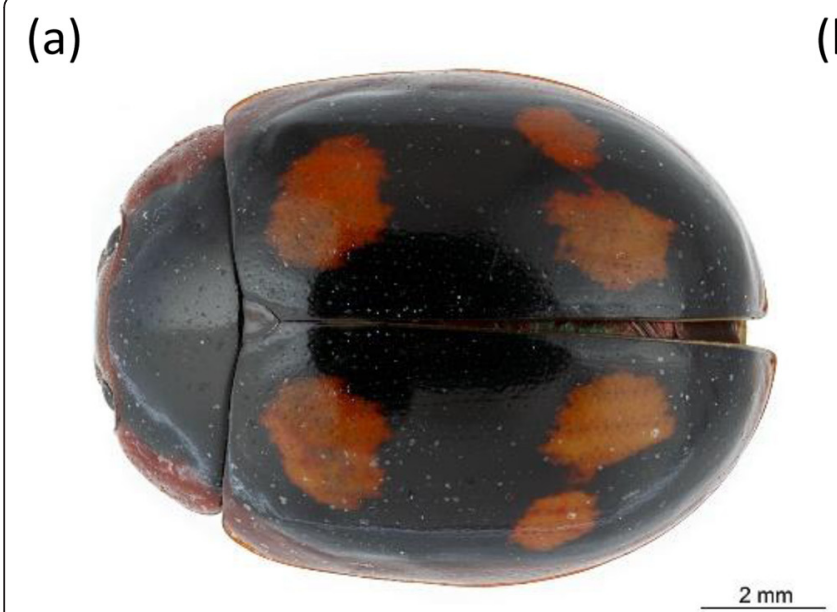

(b)

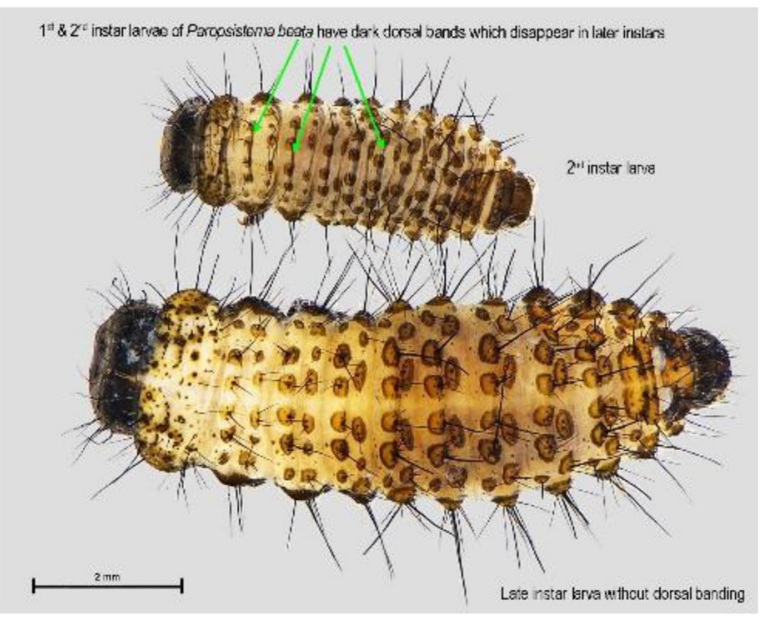

Fig. 1 Dorsal view of adult Paropsisterna beata (a), second and late instar larvae (b). Photo courtesy of Plant Health and Environmental Laboratory

on the lower leaf surfaces (Strand et al. 2014) where larvae were often observed. The spot-spraying technique used here was a modification of the spot-gun, developed to control invasive wilding pines (Gous et al. 2014) and is the first time this technology has been used for aerial application of insecticide. The aerial application targeted the feeding life stages, both adults and larvae.

The larvae of paropsine species fall to the ground and pupate in leaf litter or burrow into the soil and pupate below the surface at the completion of larval growth (Leon 1989). Ground applications targeted the pupae and emerging adults in the litter and soil. Applying ground sprays mainly during the cooler months targeted the overwintering adults seeking shelter in the litter and soil. The insecticide bifenthrin was used because it has strong adsorption to soil particles (National Pesticide Information Center, n.d.) and remains active in soil for up 125 days (Young 2013). Therefore, it is likely to continue to kill any pre-pupae, larvae or adults that may have escaped direct contact during spraying.

\section{Conclusions}

The last time $P$. beata was found was October 2013 despite a further five surveys being conducted. Other surveys conducted in other parts of New Zealand (data not shown) have not detected $P$. beata elsewhere in the country, which strongly suggests that this species has been eradicated. The success of the eradication programme can be attributed, in part, to the early detection of the incursion. However, the effective response strategy provided by MPI and cooperation from the residents of Whitemans Valley also played a significant role. The pathway by which the beetle was introduced into New Zealand remains unknown. Aerial spot-spray application provided an additional tool for incursion response in difficult and sensitive areas where targeted aerial application of insecticides is required.

\section{Endnotes}

${ }^{1}$ Cost benefit analysis: eucalyptus leaf beetle, Paropsisterna beata. (Unpublished report). Ministry for Primary Industries, New Zealand.

${ }^{2}$ Strand, T. M., Richardson, B., Schou, W., and Bulman, L. Summary of modelling results for Paropsisterna beata eradication. (Unpublished report for MPI). Rotorua, New Zealand: New Zealand Forest Research Institute Limited (Scion).

${ }^{3} \mathrm{~A}$ racemic mixture of $(\mathrm{S})-\alpha$-cyano-3-phenoxybenzyl(1R,3R)-3-(2,2-dichlorovinyl)-2,2-dimethylcyclopropanecarboxylate and (R)- $\alpha$-cyano-3-phenoxybenzyl-(1S,3S)3-(2,2-dichlorovinyl)-2,2-dimethylcyclopropanecarboxylate.

${ }^{4}$ (2-Methyl-3-phenylphenyl) methyl (1S,3S)-3-[(Z)-2chloro-3,3,3-trifluoroprop-1-enyl]- 2,2-dimethylcyclopropane-1-carboxylate.

\section{Competing interests}

The authors declare that they have no competing interests.

\section{Authors' contributions}

EY wrote the manuscript and was the response manager. DV and DG provided technical information and diagnostics, BC was second response manager and $\mathrm{DH}$ managed the response operations. All authors have read and approved the final manuscript.

\section{Acknowledgements}

MPI Operational Research and B3 Research funded the spot-gun research conducted by New Zealand Forest Research Institute Ltd (Scion). Dr. John Kean (AgResearch Ltd) provided statistical advice on the surveillance programme. AsureQuality Ltd, Hammond Resource Management, SPS Biosecurity, Heli Resources, New Zealand Biosecurity Services, Projex Maintenance and Downer Tree Services carried out the field operations. We thank the MPI Communication, Investigation (especially Travis Ashcroft) and Response teams for their immense contributions. Our final appreciation goes to the residents of Whitemans Valley for their support and cooperation. 


\section{Author details}

Ministry for Primary Industries, PO Box 2526, Wellington, New Zealand.

${ }^{2}$ Ministry for Primary Industries, PO Box 14018, Christchurch, New Zealand.

${ }^{3}$ Ministry for Primary Industries, PO Box 2095, Auckland, New Zealand.

${ }^{4}$ Hammond Resource Management Ltd, Rotorua, New Zealand.

Received: 26 October 2015 Accepted: 27 January 2016

Published online: 17 February 2016

\section{References}

Bain, J., Murray, T., Berndt, L. A., \& Gresham, B. (2009). The eucalyptus tortoise beetle (Paropsis charybdis) in New Zealand. (Forest and Timber Insects in New Zealand No. 10). Wellington: Farm Forestry New Zealand. http://www.nzffa.org.nz/ farm-forestry-model/the-essentials/forest-health-pests-and-diseases/Pests/ Paropsis-charybdis/ParopsisEnt-10. Accessed 20 Nov 2013.

Edwards, P. B., \& Suckling, D. M. (1980). Cermatulus nasalis and Oechalia schelembergi (Hemiptera: Pentatomidae) as predators of eucalyptus tortoise beetle larvae, Paropsis charybdis (Coleoptera: Chrysomelidae) in New Zealand. New Zealand Entomologist, 7(2), 158-164.

Folmer, O., Black, M., Hoeh, W., Lutz, R., \& Vrijenhoek, R. (1994). DNA primers for amplification of mitochondrial cytochrome $c$ oxidase subunit I from diverse metazoan invertebrates. Molecular Marine Biology and Biotechnology, 3, 294-297.

Gordon, P. (Ed.). (2010). New Zealand inventory of biodiversity. Vol. 2. Christchurch, New Zealand:Canterbury University Press.

Gous, S., Raal, P., \& Watt, M. S. (2014). Aerial spot treatment using an oil carrier to apply ester based herbicides for control of Pinus contorta and P. nigra in New Zealand. New Zealand Journal of Forestry Science, 44, 23.

Johns, C. V., Stone, C., \& Hughes, L. (2004). Feeding preference of the Christmas beetle Anoplognathus chloropyrus (Coleoptera: Scarabeidae) and four paropsine species (Coleoptera: Chrysomelidae) on selected Eucalyptus grandis clonal foliage. Australian Forestry, 67(3), 187-190.

Kean, J. M., Burnip, G. M., \& Pathan, A. (2015). Detection survey design for decision making during biosecurity incursions. In F. C. Jarrad, S. J. Low-Choy, \& K. Mengersen (Eds.), Biosecurity surveillance: quantitative approaches (pp. 238252). Wallingford, Oxfordshire, U.K.: CAB International.

Leon, A. (1989). The Tasmanian eucalyptus leaf beetle, Chrysophtharta bimaculata: an overview of the problem and current control methods. Tasmania, Australia: Forestry Commission.

Malumphy, C., \& Anderson, F. (2015). Tasmanian eucalyptus beetle. [Fact sheet] www.https://secure.fera.defra.gov.uk/phiw/riskRegister/plant-health/ documents/notifiable_pests/paropsisterna-selmani.pdf. Accessed 14 May 2013.

Millar, J. G., Paine, T. D., Campbell, K. A., Garrison, R. W., \& Dreistadt, S. H. (2003). Eucalyptus tortoise beetle http://cekern.ucanr.edu/files/98142.pdf. Accessed 14 May 2013.

National Pesticide Information Center (n.d.). Bifenthrin, technical fact sheet. http://npic.orst.edu/factsheets/archive/biftech.html Accessed 12 May 2013.

Strand, T. M., Rolando, C. A., Richardson, B., Gous, S., Bader, M. K. F., \& Hammond, D. (2014). An aerial spot-spraying technique: a pilot study to test a method for pest eradication in urban environments. SpringerPlus, 3, 750.

Thistle, H. W. (2003). AGDISP: USDA forest service spray modelling software, version 8.15.. Morgantown, WV, USA: USDA Forest Service.

Young, S. (2013). New Zealand Novachem Agrichemical Manual. Talstar ${ }^{\circledast} 100 E C$ (pp. 689). Christchurch, New Zealand:Agrimedia Limited.

\section{Submit your manuscript to a SpringerOpen ${ }^{\circ}$ journal and benefit from:}

- Convenient online submission

- Rigorous peer review

- Immediate publication on acceptance

- Open access: articles freely available online

High visibility within the field

- Retaining the copyright to your article 